\title{
'Candidatus Phytoplasma asteris' Strains Associated with Oil Palm Lethal Wilt in Colombia
}

Elizabeth Alvarez, Plant Pathology Program, International Center for Tropical Agriculture (CIAT), Cali, Valle del Cauca, Colombia; Juan F. Mejía, CIAT and Department of Agricultural Sciences and Technologies (DipSA), Alma Mater Studiorum, University of Bologna, Italy; Nicoletta Contaldo and Samanta Paltrinieri, DipSA; Bojan Duduk, Institute of Pesticides and Environmental Protection, Belgrade, Serbia; and Assunta Bertaccini, DipSA

\begin{abstract}
Alvarez, E., Mejía, J. F., Contaldo, N., Paltrinieri, S., Duduk, B., and Bertaccini, A. 2014. 'Candidatus Phytoplasma asteris' strains associated with oil palm lethal wilt in Colombia. Plant Dis. 98:311-318.

The distribution of lethal wilt, a severe disease of oil palm, is spreading throughout South America. An incidence of about $30 \%$ was recorded in four commercial fields in Colombia. In this study, phytoplasmas were detected in symptomatic oil palm by using specific primers, based on $16 \mathrm{~S}$ ribosomal DNA (rDNA) sequences, in nested polymerase chain reaction assays. The phytoplasmas were then identified as 'Candidatus Phytoplasma asteris', ribosomal subgroup 16SrI-B, through the use of

quencing. Cloning and sequencing of $16 \mathrm{~S}$ rDNA from selected strains, together with phylogenetic analysis, confirmed the classification. Moreover, collective RFLP characterization of the groEL, amp, and $r p$ genes, together with sequence data, distinguished the aster yellows strain detected in Colombian oil-palm samples from other aster yellows phytoplasmas used as reference strains; in particular, from an aster yellows strain infecting corn in the same country.
\end{abstract} restriction fragment length polymorphism (RFLP) analysis and se-
Production of oil palm (Elaeis guineensis Jacq.) is a recent and now major agricultural activity in Colombia. Because it constitutes a key alternative for generating employment, it is considered strategic for the national economy. However, production has declined by $7.1 \%$ since 2002. This drop occurred mainly in northeastern Colombia, where production decreased by almost $10 \%$ (17). The cause of this decrease is a disease known as "lethal wilt of oil palm" ("marchitez letal" in Spanish). Lethal wilt is present in Colombia in the Upía River area in the oil-palm plantations of Palmar del Oriente (July 1994), Palmas del Casanare (1999), Palmeras Santana (2000), and Palmeras del Upía (2002) (44). By 2010, the disease had severely infected oil palm in these areas, leading to their eradication on about 690 ha with a total of 97,619 plants (17). Symptoms of lethal wilt usually first appear as vascular discoloration and leaf yellowing when the palm is mature (i.e., flowering and fruiting) at 7 years old. These symptoms are followed by leaf drying, wilt, necrosis of infected tissues, and eventual plant collapse (Fig. 1). Root necrosis often accompanies leaf discoloration. Internal discoloration of trunk tissue may also occur but does not represent a distinctive symptom. Lethal wilt is potentially destructive because it spreads rapidly and causes plant death within 4 to 6 months after symptoms first appear (43).

The pathogen was believed to be a phytoplasma, possibly related to that associated with lethal yellowing disease, which infects other palm species such as coconut (2). Phytoplasmas have been associated with diseases in several hundred plant species (6). They are limited to the plants' phloem tissue and to insect vectors that feed

\section{Corresponding author: E. Alvarez, E-mail: e.alvarez@cgiar.org}

GenBank accession numbers: JX681021, JX681022, JX681023, KF434318, KF434319, and KF434320.

All authors have reviewed the manuscript and have approved its submission to the journal Plant Disease. The manuscript is not being submitted elsewhere.

Accepted for publication 24 September 2013.

http://dx.doi.org/10.1094/PDIS-12-12-1182-RE

(C) 2014 The American Phytopathological Society directly from phloem tissues. Vectors include planthoppers and leafhoppers in the genera Macrosteles, Euscelis, Euscelidius, Scaphoideus, and Cacopsylla (52).

Phytoplasmas are associated not only with lethal yellowing in coconut palm in many parts of the world but also with diverse palm species. Worldwide, this disease affects at least 30 species of palm, including Phoenix dactylifera (date palm), Veitchia merrilli (manila palm), Caryota rumphiana (fishtail palm), P. canariensis (Canary Island date palm), and E. guineensis (African oil palm) $(39,40)$. The disease has killed millions of coconut palm trees (Cocos nucifera) throughout the Caribbean, Florida, Mexico, and Central America $(23,24,41,42)$. In addition, a first report of phytoplasmas in symptomatic oil palm trees was confirmed by electron microscopy in West New Britain, Papua New Guinea (50). The group 16SrIV lethal yellowing phytoplasma has been shown to be vectored by Myndus crudus (American palm cixiid) and possibly also by Cedusa spp. of derbid planthoppers (8). Phytoplasmas closely related to the $16 \mathrm{SrIV}$ group have also been reported in date palm and other palm species in the United States $(22,23)$. They were also recently detected in weeds such as Emilia fosbergii, Synedrella nodiflora, and Vernonia cinerea $(9,10)$. These weeds are all members of the Asteraceae family and were collected in Jamaica near diseased coconut palm.

More recently, phytoplasmas from other 16S ribosomal groups have been associated with symptoms in palm in other parts of the world. In Saudi Arabia, a 16SrI group was found associated with the Al-Wijam disease of date palm (1). In North Sudan, a 16SrXIV group, 'Candidatus Phytoplasma cynodontis', commonly associated with bermudagrass, was found in date palm showing slow decline (11). Recently, a 16SrI phytoplasma was associated with coconut yellow decline and oil palm in Malaysia $(39,40)$. Similarly, the Weligama wilt disease of coconut in Sri Lanka was associated with phytoplasmas belonging to the $16 \mathrm{SrXI}$ ' $\mathrm{Ca}$. $\mathrm{P}$. oryzae' group. Phytoplasmas from two phylogenetic groups, $16 \mathrm{SrXI}$ and 16SrXIII, Mexican periwinkle virescence, were associated with Kalimantan wilt in Indonesia (51).

In South America, symptoms similar to those observed in Colombia were also described from oil palm in Brazil suffering from a disease known as "fatal yellowing" $(7,38)$. Although the cause of this disease is still unknown, the symptoms and distribution of the problem in both Colombian and Brazilian plantations suggest that 
infectious agents are involved (49). A preliminary study also detected phytoplasmas in symptomatic plants in commercial crops of the susceptible oil-palm hybrid (Elaeis guineensis $\times$ E. oleifera) (2) in Colombia.

Phytoplasma identification and classification rely on $16 \mathrm{~S}$ ribosomal gene analysis to identify ' $\mathrm{Ca}$. P.' species and distinguish between the $16 \mathrm{Sr}$ groups and subgroups (6). In particular, ' $\mathrm{Ca}$. $\mathrm{P}$. asteris' is classified in the $16 \mathrm{SrI}$ group, in which at least 18 subgroups are recognized (30). Finer differentiation can also be obtained by studying polymorphisms on other genes $(35,37)$ in order to monitor the spread of specific phytoplasma strains.

The large survey carried out in this work allowed us to verify phytoplasma presence in diverse tissues from diseased oil palm collected in four areas of Colombia affected by "marchitez letal". The detected aster yellows (AY) strains were then characterized on four phytoplasma genes with a multilocus typing technique that allowed comparison and distinction of the strains infecting diseased oil palm from reference strains (5) and from a strain infecting corn in Colombia.

\section{Materials and Methods}

Plant samples. Samples from 44 symptomatic and 7 asymptomatic oil palm trees were collected between 2003 and 2011 from four plantations in two sites: Villanueva (Department of Casanare) and Barranca de Upía (Department of Meta), Colombia. The four plantations belonged to plantation A: Palmar del Oriente S.A. (located at $4^{\circ} 30^{\prime} 15^{\prime \prime} \mathrm{N}$ and $72^{\circ} 56^{\prime} 20^{\prime \prime} \mathrm{W}$ ), plantation B: Palmas del Casanare S.A. $\left(4^{\circ} 35^{\prime} 58.33^{\prime \prime} \mathrm{N}\right.$ and $\left.72^{\circ} 50^{\prime} 58.74^{\prime \prime} \mathrm{W}\right)$, plantation C: Palmeras Santana Ltda. ( $4^{\circ} 32^{\prime} 24.18^{\prime \prime} \mathrm{N}$ and $\left.72^{\circ} 52^{\prime} 51.38^{\prime \prime} \mathrm{W}\right)$, and plantation D: Palmeras del Upía Ltda. $\left(4^{\circ} 26^{\prime} 8.13^{\prime \prime} \mathrm{N}\right.$ and $72^{\circ} 56^{\prime} 29.39^{\prime \prime} \mathrm{W}$ ).

Samples were taken from each symptomatic and asymptomatic plant by collecting entire meristems and about 50 to $100 \mathrm{~g}$ from each of three tissue types: chlorotic leaves, spears, and inflorescences. Three 10-by-10-cm segments were also excised from the base of the trunk, together with 1025 -cm-long root segments from the root ball of each palm at $50 \mathrm{~cm}$ from the collar. From 44 symptomatic trees, 85 samples from different tissues were tested; about half of these samples were collected from palm trees with severe symptoms (see below). Comparable tissues from seven asympto- matic plants were collected at the same time from all four plantations surveyed (three plants from plantation A, two from B, and one plant each from plantations $\mathrm{C}$ and $\mathrm{D})$. In total, 44 samples were tested as negative controls.

A symptom severity scale was used to rate each symptomatic plant, where 1 represented a dead inflorescence and fruit rot, $2=$ chlorosis or necrosis of the oldest leaves, $3=$ leaf chlorosis in the upper canopy, and $4=$ a dead spear leaf and apical meristem rot. Plants receiving a score of 1 or 2 were characterized as having mild symptoms, 2 or 3 as having moderate symptoms, and 3 or 4 as having severe symptoms. The ability to detect phytoplasmas from infected tissues was then compared between plants with mild symptoms and those exhibiting severe symptoms.

Detecting and identifying phytoplasmas. DNA was extracted from 0.4 to $1.0 \mathrm{~g}$ of tissues from each plant sample, according to previously described protocols $(19,44)$. Tissue samples were frozen and ground in liquid nitrogen using a sterilized mortar and pestle. After the final ethanol precipitation, nucleic acid extracts were resuspended in 30 to $50 \mu \mathrm{l}$ of Tris-EDTA buffer $(10 \mathrm{mM}$ Tris-HCl [pH 8.0] and $1 \mathrm{mM}$ EDTA [pH 8.0]) and stored at $-20^{\circ} \mathrm{C}$.

The phytoplasma universal primer pair P1/P7 $(13,46)$ was used to amplify DNA from the $16 \mathrm{Sr}$ region and the beginning of the $23 \mathrm{~S}$ ribosomal DNA (rDNA) genes, including the internal spacer region. Nested polymerase chain reaction (PCR) assays were performed on amplicons diluted at 1:29 with sterilized high-performance liquid chromatography-grade water, using primers $\mathrm{R} 16 \mathrm{~F} 2 \mathrm{n} /$ R2 (20). Each PCR reaction was carried out in $0.5-\mathrm{ml}$ tubes in $25-\mu \mathrm{l}$ reactions, using final concentrations of $20 \mathrm{ng}$ of DNA, $1 \times$ buffer, Taq polymerase (Sigma-Aldrich) at $0.05 \mathrm{U} / \mu \mathrm{l}, 0.2 \mathrm{mM}$ dNTPs (Invitrogen Life Technologies), and $0.4 \mu \mathrm{M}$ each primer.

Positive controls employed for the molecular analyses included DNA from phytoplasma reference strains that represented different ribosomal 16S rDNA subgroups. These strains either had been maintained in periwinkle (Catharanthus roseus (L.) G. Don.) or were extracted from the original host plant, as for maize bushy stunt from Colombia (Table 1). Samples devoid of DNA template and from asymptomatic oil palm trees were added as negative controls for the PCR reactions.

Direct and nested-PCR assays were carried out in a PTC-100 thermal cycler with a heated lid (MJ Research, Inc.), using the
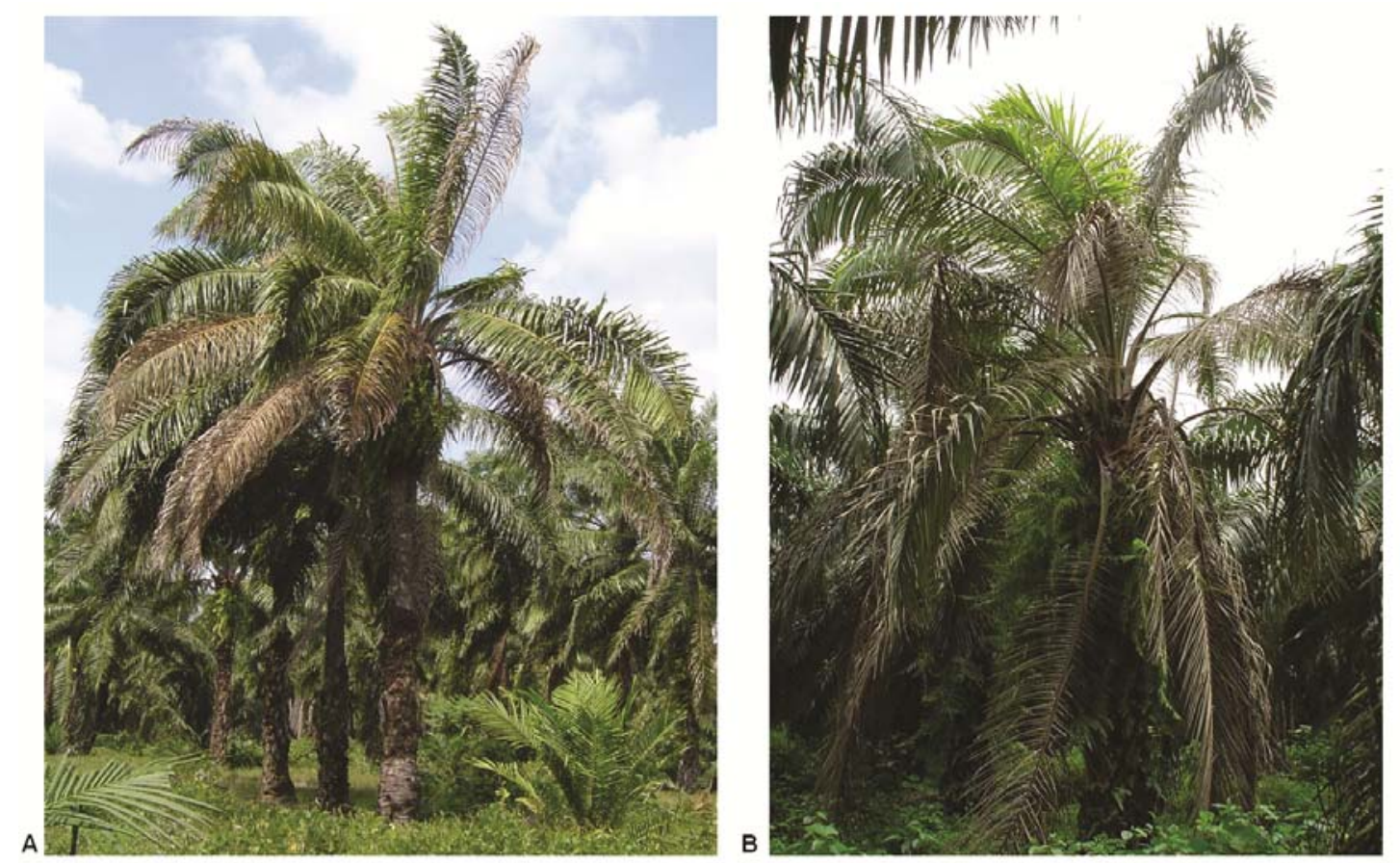

Fig. 1. Two diseased oil palm plants in Colombia, A, one with mild symptoms (severity score of 1 or 2) and B, the other with severe symptoms (severity score of 3 or 4 ) of lethal wilt. 
following thermal profile: $30 \mathrm{~s}$ ( $90 \mathrm{~s}$ for the first cycle) of denaturation at $94^{\circ} \mathrm{C}$, annealing for $50 \mathrm{~s}$ at $55^{\circ} \mathrm{C}$, and extension of the primer for $80 \mathrm{~s}\left(10 \mathrm{~min}\right.$ in the final cycle) at $72^{\circ} \mathrm{C}$. For primer pair R16F2n/R16R2, amplifying about 1,200 bp within the 16S rDNA region in nested-PCR assays, the annealing temperature was $50^{\circ} \mathrm{C}$. The PCR products were visualized in a $1.5 \%$ agarose gel, stained with ethidium bromide at $0.75 \mu \mathrm{g} / \mathrm{ml}$, and analyzed in a Stratagene Eagle Eye II video system.

The 98 amplicons obtained with the R16F2n/R16R2 primers $(1.2 \mathrm{~kb})$ were then digested with restriction enzymes TrulI and HhaI (Fermentas), following the manufacturer's instructions. Separation of bands generated from restriction digestion was performed in $6.7 \%$ polyacrylamide gels. The DNA was then stained and visualized as described above.

Direct sequencing in both directions (using primers P1/F1 [12] as forward primers and P7 as reverse primer) was performed on the P1/P7 amplicons after purification with a QIAquick PCR Purification Kit (Qiagen). The sequences were assembled using Sequencher 4.1 software. They were then compared with selected nucleotide sequences in the GenBank database using BLAST (version BLASTN 2.2.18; National Center for Biotechnology Information $[\mathrm{NCBI}])$.

Sequence alignments were performed using ClustalX and BioEdit $(21,48)$. Before constructing phylogenetic trees, all sequences were trimmed to contain only $16 \mathrm{~S}$ rDNA (1,245 bp). Phylogenetic analyses were carried out on 16S rDNA sequences from oil palm and from several 'Candidatus' phytoplasma strains using Acholeplasma laidlawii as the outgroup. GenBank accession numbers and other sources of 16S rRNA gene sequences used in phylogenetic analyses are given in Table 1. Phylogenetic trees were constructed with maximum parsimony analysis, using the Close-Neighbor-Interchange algorithm, with the initial tree created by random addition for 10 replications of neighbor-join- ing method, using MEGA version 5 (47). For all methods, all default values (gaps excluded) were performed with 1,000 replications for bootstrap analysis to estimate stability and support for the clades.

Strain characterization on groEL, $r p$, and amp genes. These gene regions were chosen because they were useful in distinguishing among phytoplasma strains in several studies $(28,35,37)$. Amplification was carried out on 44 positive oil-palm samples obtained from previous phytoplasma identification on the 16S rDNA gene (one per plant).

The samples were employed for amplification in nested PCR with groEL primers AYgroesF/AYampR, followed by AYgroelF/ AYgroelR amplicons, diluted at 1:30 as described in published protocols $(36,37)$. The negative and positive controls were as described above. Restriction fragment length polymorphism (RFLP) analyses were carried out on amplicons using AluI and TrulI restriction enzymes (Fermentas) according to the manufacturer's instructions. Restriction fragments were separated as described above. Direct sequencing and sequence assembly were performed on the AYgroelF/AYgroelR amplicon from sample OP47. A phylogenetic tree was produced, using available reference strains (Table 1), as described above.

Previous studies indicated that the part of the ribosomal operon that includes the complete $l 22$ and $s 3$ genes can be used as a phylogenetic marker, because it has finer resolving power for differentiating distinct phytoplasma strains in 16S rDNA subgroups (35). The 44 oil-palm samples were employed for direct amplification with the $\mathrm{rpF} 1 / \mathrm{rpR} 1$ primer pair (33) using the reaction mix and the negative and positive controls, as described above. Thirty-eight PCR cycles were conducted under the following conditions: 1 min ( 2 min for the first cycle) for denaturation step at $94^{\circ} \mathrm{C}, 2 \mathrm{~min}$ for annealing at $55^{\circ} \mathrm{C}$, and $3 \mathrm{~min}(10 \mathrm{~min}$ for the last cycle) for primer extension at $72^{\circ} \mathrm{C}$. RFLP analyses of obtained amplicons with

Table 1. Aster yellows-related reference phytoplasma ('Candidatus Phytoplasma asteris') strains employed for 16S ribosomal DNA (rDNA), groEL, ribosomal protein $l 22$, and $s 3$ characterization

\begin{tabular}{|c|c|c|c|c|c|c|c|c|}
\hline \multirow[b]{2}{*}{ Disease (acronym) $)^{\mathbf{b}}$} & \multirow[b]{2}{*}{ Geographic origin } & \multicolumn{3}{|c|}{ GenBank accession numbers } & \multicolumn{3}{|c|}{ RFLP classification $^{\mathbf{a}}$} & \multirow[b]{2}{*}{ References } \\
\hline & & 16S rDNA & groEL & $r p$ & 16SrI & groELI & $r p \mathbf{I}$ & \\
\hline New Jersey aster yellows (NJ-AY) & New Jersey & HM590622 & AB599703 & - & A & I & A & $31,35,37$ \\
\hline Plantago virescence (PVM) & Germany & AY265216 & AB599706 & AY264867 & A & I & A & $5,35,37$ \\
\hline Carrot yellows (ca2006/1) & Serbia & EU215424 & AB599708 & EU215428 & A & I & A & 14,37 \\
\hline Gray dogwood stunt (GD1) & New York & DQ112021 & AB599694 & AY264864 & A & II & M & 32,37 \\
\hline Periwinkle virescence (NA) & Italy & HM590621 & AB599702 & - & B & III & - & 5,37 \\
\hline Primula green yellows (PrG) & United Kingdom & HM590623 & AB599696 & - & $\mathrm{B}$ & III & - & 5,37 \\
\hline Oilseed rape virescence $(\mathbf{R V})$ & France & HM590625 & AB599698 & - & B & III & - & 5,37 \\
\hline Carrot yellows (ca2006/9) & Serbia & EU215426 & AB599709 & EU215430 & B & III & B & 14,37 \\
\hline Primrose virescence (PRIVA) & Germany & AY265210 & AB599705 & - & $\mathrm{B}(\mathrm{L})$ & III & B & 35,45 \\
\hline Aster yellows (AV2192) & Germany & AY180957 & AB599687 & AY183708 & $\mathrm{B}(\mathrm{L})$ & III & B & $34,35,37$ \\
\hline Aster yellows (AVUT) & Germany & AY265209 & AB599686 & AY264855 & $\mathrm{B}(\mathrm{M})$ & III & B & $34,35,37$ \\
\hline Aster yellows (AY-J) & France & HM590616 & AB599689 & - & B & IV & - & 37 \\
\hline Carrot yellows (ca2006/5rrnA) & Serbia & EU215425/ & AB599711 & EU215429 & $\mathrm{B}(?)$ & IV & - & 14,37 \\
\hline Carrot yellows (ca2006/5rrnB) & Serbia & GQ175789 & & & & & & \\
\hline Maize bushy stunt (MBS Col) & Colombia & HQ530152 & AB599712 & KF434319 & B & $\mathrm{V}$ & - & $15,37, \mathrm{UP}^{\mathrm{c}}$ \\
\hline Maize bushy stunt (MBS) & Mexico & AY265208 & - & AY264858 & B & - & $\mathrm{L}$ & 30 \\
\hline Oil palm lethal wilt (OP47) & Colombia & JX681021 & JX681023 & KF434318 & B & $\mathrm{V}$ & - & This work \\
\hline Leontodon yellows (LEO) & Italy & HM590620 & AB599701 & - & $\mathrm{C}$ & VI & - & 5,37 \\
\hline Carrot yellows (CA) & Italy & HM448473 & AB599690 & - & $\mathrm{C}$ & VI & - & 5,37 \\
\hline Clover phyllody (KVE) & France & AY265217 & - & AY264861 & $\mathrm{C}$ & - & $\mathrm{C}$ & 30,35 \\
\hline Clover phyllody (KVF) & France & HQ530150 & AB599695 & - & $\mathrm{C}$ & VII & - & 34,37 \\
\hline Potato purple top (PPT) & France & HQ530151 & AB599704 & - & $\mathrm{C}$ & VII & - & 34,37 \\
\hline Paulownia witches' broom (PaWB) & Taiwan & AY265206 & AB124810 & AY264857 & $\mathrm{D}$ & - & $\mathrm{D}$ & 28,30 \\
\hline Blueberry stunt (BBS3) & Mississippi & AY265213 & - & AY264863 & $\mathrm{E}$ & - & E & 30 \\
\hline Aster yellows apricot (A-AY) & Spain & AY265211 & AB599699 & AY264866 & $\mathrm{F}$ & VIII & $\mathrm{N}$ & 30,37 \\
\hline Strawberry multiplier (STRAWB2) & Florida & U96616 & - & U96617 & $\mathrm{K}$ & - & $\mathrm{J}$ & 30 \\
\hline $\begin{array}{l}\text { Ipomea obscura witches' broom } \\
\text { (IOWB) }\end{array}$ & Taiwan & AY265205 & - & AY264859 & $\mathrm{N}$ & - & $\mathrm{F}$ & 30,34 \\
\hline Populus decline (PopD) & Serbia & HM590626 & AB599710 & - & $\mathrm{P}$ & IX & - & 37 \\
\hline
\end{tabular}

${ }^{a}$ Different letter represent diverse restriction fragment length polymorphism (RFLP) subgroups in the 16S rDNA and $r p$ I genes of aster yellows strains and different Roman number represent diverse RFLP groups in the groEL gene; (?) refers to a strain with interoperon heterogeneity that is tentatively classified in this subgroup; - refers to a sequence not available in the GenBank.

${ }^{\mathrm{b}}$ Phytoplasma-associated disease. Strains in bold were used as references for polymerase chain reaction RFLP analysis.

${ }^{\mathrm{c}} \mathrm{UP}=$ unpublished. 
Tru1I, Hpy8I, TaaI, and AluI were then performed. The rpF1/rpR1 fragment of OP47 samples was also sequenced as described above and a search for the presence of single-nucleotide polymorphisms (SNPs) in comparison with reference strains was also carried out using MEGA version 5 (47) (Table 2).

The amp gene codes for a surface membrane protein that was recently reported as being involved in insect-to-phytoplasma transmission. Therefore, it is also suitable for phytoplasma strain differentiation (4,28). Direct PCR assays with Amp-N1/C1 primers, which amplify $702 \mathrm{bp}$ of the $a m p$ gene, were carried out according to reported procedures (29). The 44 oil-palm samples tested and the negative and positive controls were all as described above. RFLP profiles generated with TruI and Tsp509I were compared with those of the reference strains (Table 1). Direct sequencing and sequence assembly were performed on the amplicon from sample OP47. A phylogenetic tree was produced using available reference strains (Table 1), as described above. The full sequence of the amp gene was also analyzed with translated nucleotide query, using BLASTP (version BLASTP 2.2.18; NCBI) (Table 3).

\section{Results}

Detecting and identifying phytoplasmas. Nested-PCR assays amplified 1.2-kb DNA fragments of the $16 \mathrm{~S}$ rDNA in samples from the various tissues tested at different percentages. The assays detected phytoplasmas in samples from all 44 symptomatic oilpalm plants from the four plantations surveyed. All samples collected from the seven asymptomatic plants, together with the template without nucleic acid, were negative according to nested PCR.

Symptoms were evaluated and compared with phytoplasma detection percentages in the diverse oil-palm tissues showing symptoms at different stages in two localities (A and B; Fig. 2). Leaves or spears showed 86 to $100 \%$ incidence of phytoplasma detection in samples collected from plants with either mild (scoring 1 or 2) or severe (scoring 3 or 4 ) symptoms. Tissues from roots and trunks resulted in only 10 to $60 \%$ incidence of phytoplasma detection, regardless of symptom severity. RFLP analysis of the $1.2-\mathrm{kb} 16 \mathrm{~S}$ rDNA amplicons indicated that a phytoplasma belonging to subgroup 16SrI-B (' $\mathrm{Ca}$. P. asteris') was present in all symptomatic oil palm plants. RFLP patterns from the positive samples were indis-

Table 2. Differential single-nucleotide polymorphism (SNP) positions in ribosomal protein $s 3$ sequences of 15 'Candidatus Phytoplasma asteris' strains compared with OP47 (Oil palm lethal wilt)

\begin{tabular}{|c|c|c|c|c|c|c|c|c|c|c|c|c|}
\hline \multirow[b]{2}{*}{ Strain } & \multicolumn{12}{|c|}{ SNP positions in ribosomal protein $s 3^{\mathrm{a}}$} \\
\hline & 18 & 124* & 139 & 252 & $277^{*}$ & $278^{*}$ & $285 *$ & 444* & 486 & 571 & $667 *$ & 673 \\
\hline OP47 & $\mathrm{C}$ & $\mathrm{C}$ & A & $\mathrm{T}$ & $\mathrm{A}$ & A & $\mathrm{C}$ & $\mathrm{T}$ & $\mathrm{C}$ & $\mathrm{C}$ & $\mathrm{C}$ & A \\
\hline MBS Col & . & A & . & . & . & . & . & . & . & . & . & . \\
\hline MBS & $\mathrm{T}$ & . & . & . & G & . & . & . & $\dot{.}$ & $\dot{.}$ & $\dot{0}$ & $\dot{.}$ \\
\hline PVM & $\mathrm{T}$ & . & G & $\mathrm{C}$ & $\mathrm{G}$ & $\mathrm{C}$ & $\mathrm{T}$ & A & $\mathrm{T}$ & G & $\mathrm{T}$ & $\mathrm{G}$ \\
\hline ca2006/1 & $\mathrm{T}$ & . & $\mathrm{G}$ & $\mathrm{C}$ & $\mathrm{G}$ & $\mathrm{C}$ & $\mathrm{T}$ & A & $\mathrm{T}$ & $\mathrm{G}$ & $\mathrm{T}$ & $\mathrm{G}$ \\
\hline GD1 & $\mathrm{T}$ & . & G & $\mathrm{C}$ & G & $\mathrm{C}$ & $\mathrm{T}$ & A & . & G & $\mathrm{T}$ & G \\
\hline ca2006/9 & $\mathrm{T}$ & . & . & . & $\mathrm{G}$ & $\mathrm{C}$ & . & . & $\mathrm{T}$ & G & . & $\mathrm{G}$ \\
\hline AV2192 & $\mathrm{T}$ & . & . & . & G & $\mathrm{C}$ & . & . & $\mathrm{T}$ & $\mathrm{G}$ & . & $\mathrm{G}$ \\
\hline AVUT & $\mathrm{T}$ & . & . & . & $\mathrm{G}$ & $\mathrm{C}$ & . & . & $\mathrm{T}$ & G & . & $\mathrm{G}$ \\
\hline ca2006/5 & $\mathrm{T}$ & . & . & . & G & . & . & . & . & . & . & $\mathrm{G}$ \\
\hline KVE & $\mathrm{T}$ & . & G & $\mathrm{C}$ & G & $\mathrm{C}$ & A & A & $\mathrm{T}$ & G & . & G \\
\hline PaWB & $\mathrm{T}$ & . & . & . & G & $\mathrm{C}$ & . & . & $\mathrm{T}$ & G & . & $\mathrm{G}$ \\
\hline BBS3 & $\mathrm{T}$ & . & G & $\mathrm{C}$ & G & $\mathrm{T}$ & . & A & $\mathrm{T}$ & G & . & $\mathrm{G}$ \\
\hline A-AY & $\mathrm{T}$ & . & $\mathrm{G}$ & $\mathrm{C}$ & $\mathrm{G}$ & $\mathrm{C}$ & . & A & $\mathrm{T}$ & G & $\mathrm{T}$ & $\mathrm{G}$ \\
\hline STRAWB2 & $\mathrm{T}$ & . & G & $\mathrm{C}$ & G & $\mathrm{T}$ & . & A & $\mathrm{T}$ & G & . & G \\
\hline IOWB & $\mathrm{T}$ & . & . & $\mathrm{C}$ & G & $\mathrm{C}$ & . & . & $\mathrm{T}$ & $\mathrm{T}$ & . & $\mathrm{G}$ \\
\hline
\end{tabular}

${ }^{a}$ Asterisk $(*)$ indicates SNPs making differential restriction sites for restriction fragment length polymorphism differentiation: 124 and 278 (Hpy8I), 277 and 285 (TrulI), 444 (AluI), and 667 (TaaI). Dots represent nucleotides identical to the OP47 consensus sequence.

Table 3. Aster yellows-related reference phytoplasma strains employed for amp characterization and their homology percentages

\begin{tabular}{|c|c|c|c|c|c|c|}
\hline \multirow[b]{2}{*}{ Phytoplasma-associated disease (acronym) ${ }^{a}$} & \multirow[b]{2}{*}{ Origin $^{b}$} & \multirow[b]{2}{*}{ GenBank $^{\mathbf{c}}$} & \multirow[b]{2}{*}{ 16SrI RFLPd } & \multicolumn{2}{|c|}{$\begin{array}{c}\text { Nucleotide (nt) and amino } \\
\text { acid (aa) identity (\%) }\end{array}$} & \multirow[b]{2}{*}{ Reference } \\
\hline & & & & nt & aa & \\
\hline Oil palm lethal wilt (OP47) & Colombia & JX681022 & $\mathrm{B}$ & 100 & 100 & This work \\
\hline Maize bushy stunt (MBS Col) & Colombia & KF434320 & $\mathrm{B}$ & 100 & 100 & Unpublished \\
\hline Paulownia witches' broom (PaWB) & Taiwan & $\mathrm{AB} 124810$ & $\mathrm{D}$ & 95.3 & 89.5 & 28 \\
\hline Onion yellows (OYW) & Japan & $\mathrm{AB} 124806$ & $\mathrm{~B}$ & 98.6 & 95.7 & 28 \\
\hline Periwinkle leaf yellowing (PLY) & Taiwan & GQ845122 & - & 98.3 & 94.8 & Unpublished \\
\hline Chrysanthemum yellows phytoplasma (CY) & Italy & DQ787852 & $\mathrm{B}$ & 95.3 & 89.5 & 18 \\
\hline Onion yellows (OY-M) & Japan & $\mathrm{AB} 124807$ & $\mathrm{~B}$ & 97.6 & 95.2 & 28 \\
\hline Onion yellows (OY-NIM) & Japan & $\mathrm{AB} 124808$ & $\mathrm{~B}$ & 96.3 & 95.2 & 28 \\
\hline Mulberry dwarf (MD) & $\ldots$ & AB124809 & - & 91.6 & 93.8 & 28 \\
\hline Rape virescence (RV) & France & AF244540 & $\mathrm{B}$ & 97.6 & 84.2 & 4 \\
\hline Bermudagrass white leaf (AYBG) & Thailand & $\mathrm{AB} 124811$ & $\mathrm{~B}$ & 97.9 & 95.2 & 28 \\
\hline Iceland poppy yellows (IPY) & Japan & AB242234 & $\mathrm{B}$ & 98.3 & 95.2 & 28 \\
\hline Eggplant dwarf (ED) & Japan & AB242231 & $\mathrm{B}$ & 98.4 & 94.8 & 28 \\
\hline Sumac witches' broom (SWB) & Japan & AB242236 & - & 90.6 & 95.3 & 28 \\
\hline Porcelain vine witches' broom (PvWB) & Korea & AB242237 & - & 92.3 & 80.9 & 28 \\
\hline Lettuce yellows (LeY) & Japan & AB242233 & $\mathrm{B}$ & 98.1 & 83.7 & 28 \\
\hline Marguerite yellows (MarY) & Japan & $\mathrm{AB} 242235$ & $\mathrm{~B}$ & 98.7 & 94.4 & 28 \\
\hline Tomato yellows (TY) & Japan & AB242232 & $\mathrm{B}$ & 98.4 & 96.1 & 28 \\
\hline
\end{tabular}

a Oil palm phytoplasma strain used for similarity comparison shown in bold.

${ }^{\mathrm{b}}$ Geographic origin.

${ }^{\mathrm{c}}$ GenBank accession number.

d 16 SrI restriction fragment length polymorphism (RFLP) classification; - indicates "not described as a ribosomal group". 
tinguishable from each other and from phytoplasma reference strains belonging to subgroup 16SrI-B (Fig. 3A). Phytoplasma strain OP47, obtained from a palm hybrid growing in a Palmar del Oriente field, was then selected for further molecular characterization. The 1,491-bp 16S rDNA sequence was deposited in GenBank under accession number JX681021 (Table 1) and showed 99\% with a number of strains in group $16 \mathrm{SrI}$, ' $\mathrm{Ca}$. P. asteris'. The sequence of strain OP47 was then employed for phylogenetic analysis and 20 equally parsimonious trees were constructed, using 27 additional strains of AY phytoplasmas from different crops (Table 1). Results confirmed its placement in the $16 \mathrm{SrI}$ group (Fig. 4A).

Strain characterization on groEL, $\boldsymbol{r p}$, and $\boldsymbol{a m p}$ genes. The expected length (about $1.4 \mathrm{~kb}$ ) of the amplicons of the partial groEL gene was amplified from 21 of the 44 oil-palm samples tested.

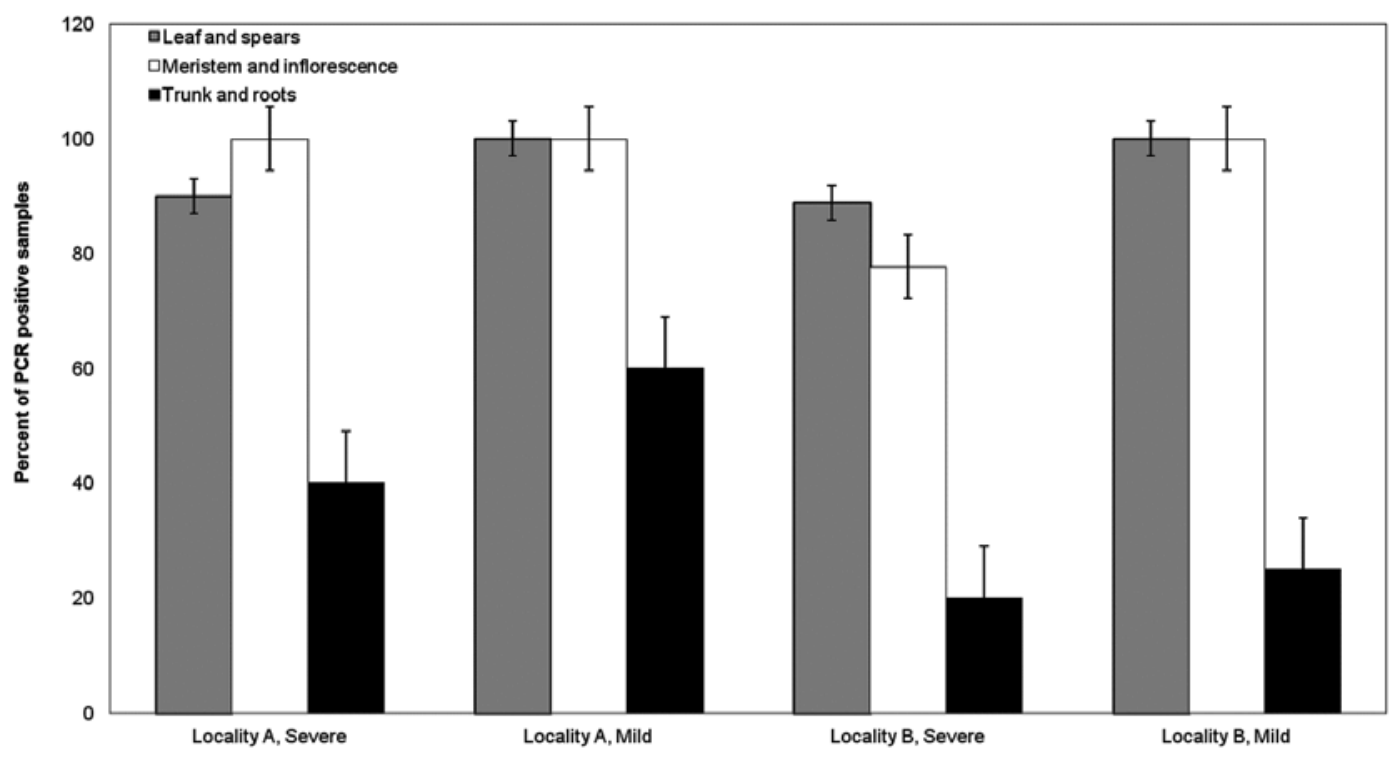

Fig. 2. Oil palm wilt symptoms observed in relation to percentage of phytoplasma detection in samples from diverse host tissues in localities A and B. Severity scale: mild symptoms with a score of 1 or 2; severe symptoms, 3 or 4 . Vertical bars represent standard errors of the means. Two-way analysis of variance for phytoplasma detection related to symptomatic tissues tested indicated significant differences between tissue types sampled $(F=57.81$ at $P<0.001)$ and no significant differences between phytoplasma detection and symptom severity or geographic locality ( $F=4.90$ at $P=0.0624$ and $F=6.45$ at $P=0.0387$, respectively).
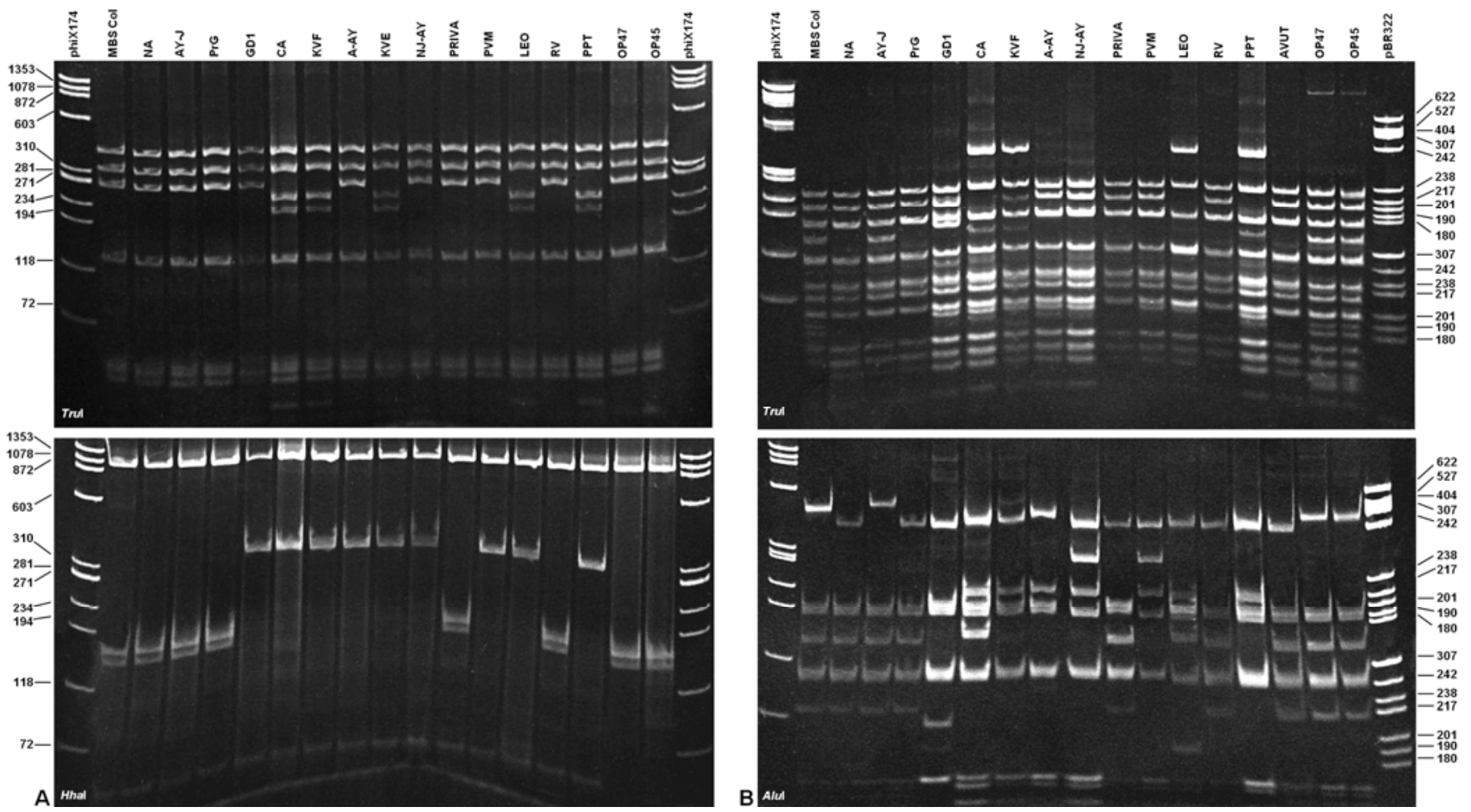

Fig. 3. Restriction fragment length polymorphism patterns of oil-palm phytoplasma strains OP45 and OP47 compared with those of several reference strains from periwinkle. A, Phytoplasma 16S ribosomal DNA amplified in nested polymerase chain reaction (PCR) with R16F2n/R16R2 primers and digested with Tru1l and Hhal restriction enzymes. B, Phytoplasma groEL gene amplified in nested PCR with AYgroelF/R primers and digested with Tru1l and Alul restriction enzymes. Strains employed were maize bushy stunt Colombia (MBS Col); periwinkle virescence (NA); aster yellows (AY-J); primula green yellows (PrG); gray dogwood stunt (GD1); carrot yellows (CA); clover phyllodyFrance (KVF); aster yellows from apricot (A-AY); clover phyllody-England (KVE); New Jersey aster yellows (NJ-AY); primrose virescence (PRIVA); plantago virescence (PVM); leontodon yellows (LEO); oilseed rape virescence (RV); potato purple top (PPT); aster yellows Germany (AVUT) Markers: phiX174, phiX174 Haelll digested; and pBR322, pBR322 Hael digested. 

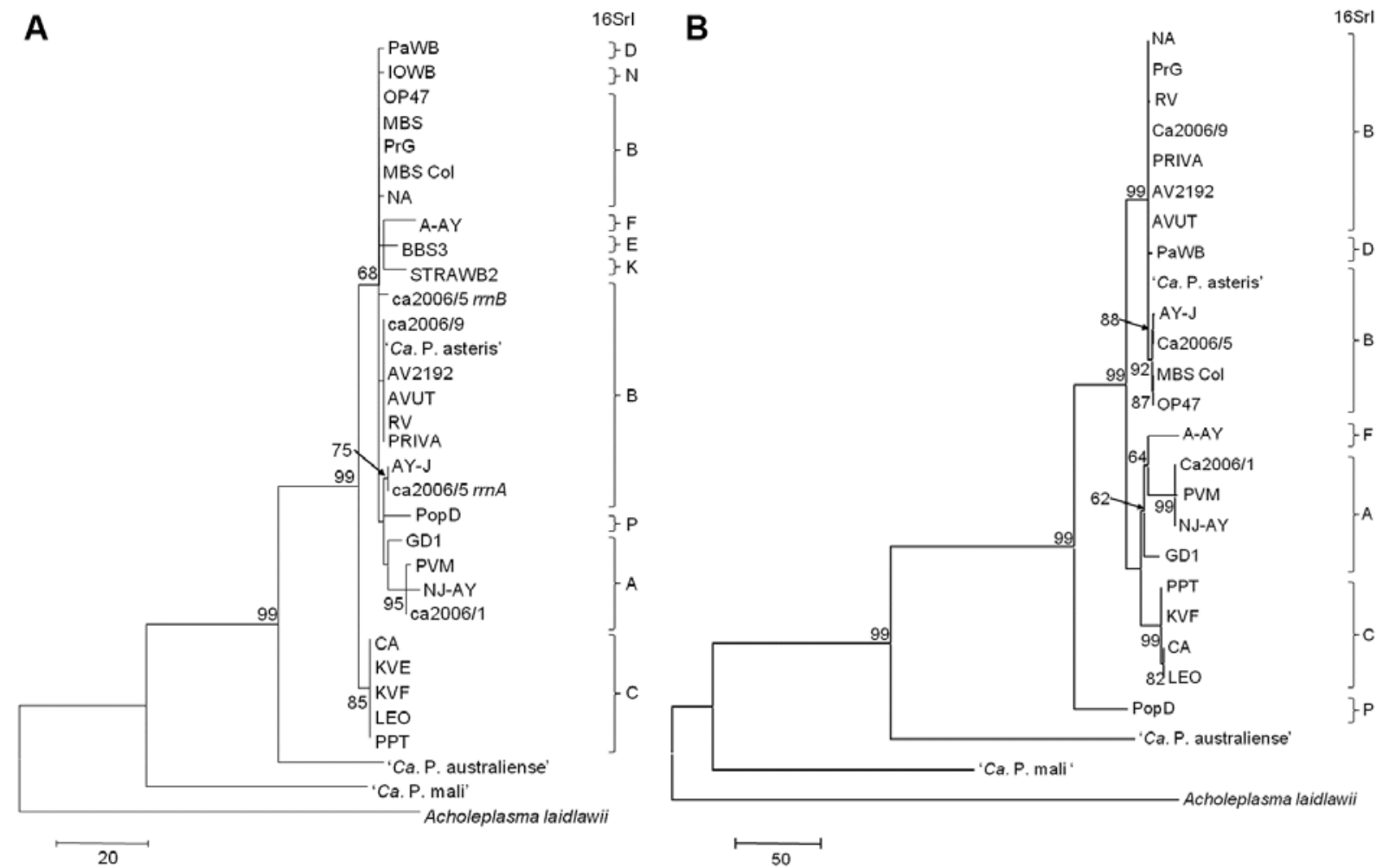

Fig. 4. Phylogenetic trees constructed by maximum parsimony analysis of $\mathbf{A}, 16 \mathrm{~S}$ ribosomal $D N A$ gene sequences and $\mathbf{B}$, groEL gene sequence from selected phytoplasma strains. Strains employed were paulownia witches' broom (PaWB); Ipomea obscura witches' broom (IOWB); oil-palm lethal wilt (OP47); maize bushy stunt (MBS); primula green yellows (PrG); maize bushy stunt Colombia (MBS Col); periwinkle virescence (NA); aster yellows apricot (A-AY); blueberry stunt (BBS3); strawberry multiplier (STRAWB2); carrot yellows (ca2006/5rrnA; ca2006/5rrnB; ca2006/5); carrot yellows (ca2006/9); 'Candidatus Phytoplasma asteris' strain OY-M (NC_005303); aster yellows (AY2192); aster yellows (AVUT); oilseed rape virescence (RV); primrose virescence (PRIVA); aster yellows (AY-J); Populus decline (PopD); gray dogwood stunt (GD1); plantago virescence (PVM); New Jersey aster yellows (NJ-AY); carrot yellows (ca2006/1); carrot yellows (CA); clover phyllody England (KVE); clover phyllody France (KVF); leontodon yellows (LEO); potato purple top (PPT);. 'Ca. P. australiense' (NC 010544); 'Ca. P. mali' strain AT (NC 011047); and Acholeplasma laidlawii PG-8A (CP000896). Numbers on the branches are bootstrap values obtained for 1,000 replicates (only values above $60 \%$ are shown).

They showed identical RFLP profiles after TrulI and AluI digestion. This profile was identical to the one observed in maize bushy stunt (MBS) strain from Colombia, thus differentiating AY phytoplasmas in oil palm from other AY strains and assigning them to the groELI RFLP subgroup V (Fig. 3B). The groEL sequence from OP47 (1,397 bp) was deposited in GenBank under accession number JX681023. The phylogenetic tree confirmed the differentiation of phytoplasmas from oil palm and maize from Colombia (Fig. 4B).

PCR assays with the $\mathrm{rpF} 1 / \mathrm{rpR} 1$ primer pair amplified the expected fragment length of about $1,200 \mathrm{bp}$ from 18 oil-palm samples. RFLP analyses with four restriction enzymes produced restriction profiles that were identical to each other and allowed clear differentiation of the two oil-palm phytoplasma strains from all the other AY strains, including maize from Colombia (Fig. 5). The $\mathrm{rpF} 1 / \mathrm{rpR} 1$ sequence from OP47 (1,168 bp) was deposited in GenBank under accession number KF434318. The SNP comparison confirmed the differentiation of phytoplasmas from oil palm and maize from Colombia in the restriction site Hpy8I (Table 2). However the further differentiation observed after RFLP analyses with $A l u \mathrm{I}$ and TaaI that allow distinguishing oil palm AY phytoplasma from maize as well as from all other reference strains employed was not retrieved in SNP comparison, presumably due to the position of the sequenced fragment outside of the $r p$ gene.

Amplification of the amp gene was obtained for 22 samples. Restriction analysis showed RFLP profiles of all strains from oil palm to be identical to each other and to the one from maize (data not shown). Sequencing and alignment for oil-palm strain OP47 provided a 702-bp sequence. It was deposited in GenBank under accession number JX681022. This sequence encodes 233 amino acids, and its predicted translation showed no significant similarities to any predicted amino acid sequence of AY phytoplasmas available in GenBank (Table 3). The phylogenetic tree confirmed the differentiation of phytoplasmas from oil palm and maize in Colombia from other strains tested (data not shown).

\section{Discussion}

The results of this study confirmed the association of a phytoplasma strain related to ' $C a$. P. asteris' with oil palm severely affected by a lethal wilt in Colombia. The work carried out expanded knowledge of this oil palm disease because a large geographic area was surveyed and a range of samples from different parts of the plants and from different stages of the disease were examined. Considering the sampling sites from which plants were tested and the presence of phytoplasmas in at least one of the samples from each symptomatic plant, the association of the disease with AY phytoplasmas is clear.

The 16S rDNA is a valuable classification tool but it is not always able to discriminate phytoplasma strains. The fine-scale molecular characterization of the phytoplasma from oil palm indicates that it can be differentiated from all other phytoplasmas in the same ribosomal subgroup enclosing those infecting corn in Colombia. Multilocus sequence analysis on amp, groEl, and $r p$ genes indicated that they could be useful molecular markers to follow the Colombian oil palm epidemic.

Only some of the diverse types of samples tested from symptomatic oil palm were negative in PCR assays. This result may be explained by uneven phytoplasma distribution in woody hosts, as recently described $(3,16)$. The amplification of other genes allowed finer characterization of the phytoplasma strain infecting oil palm in Colombia, and indicated that it can be differentiated from all the other phytoplasma strains in the AY group, including an MBS strain from Colombia (15). To our knowledge, this is the first study in which the phytoplasma previously associated with lethal wilt of 

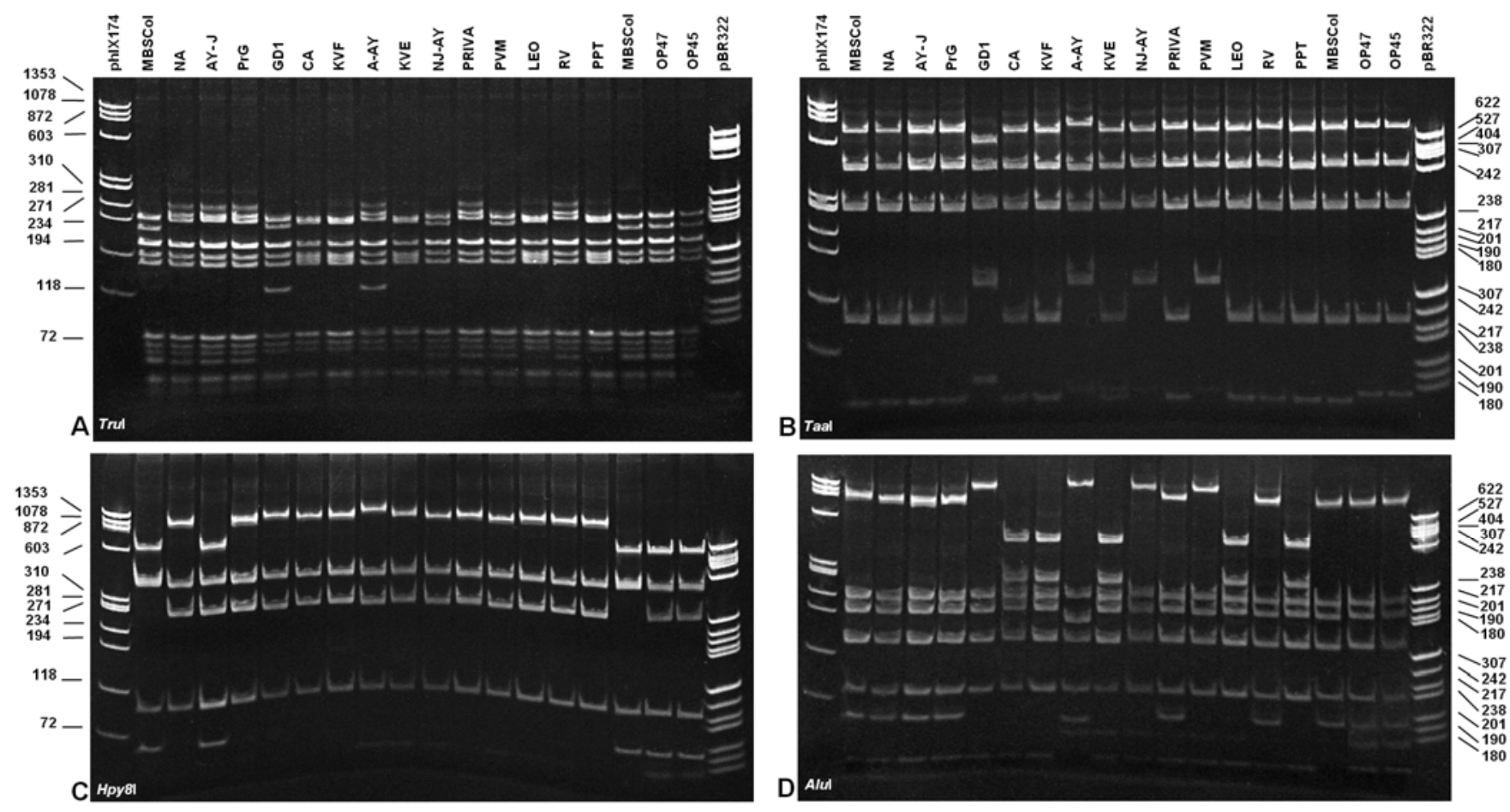

Fig. 5. Restriction fragment length polymorphism patterns of oil-palm phytoplasma strains OP45 and OP47 compared with several reference strains from periwinkle that were amplified with primers rpF1/rpR1 and digested with restriction enzymes A, Trul; B, Taal; C, Hpy8l, and D, Alul. Strains employed were maize bushy stunt Colombia (MBS Col); periwinkle virescence (NA); aster yellows (AY-J); primula green yellows (PrG); gray dogwood stunt (GD1); carrot yellows (CA); clover phyllody-France (KVF); aster yellows from apricot (A-AY); clover phyllody-England (KVE); New Jersey aster yellows (NJ-AY); primrose virescence (PRIVA); plantago virescence (PVM); leontodon yellows (LEO); oilseed rape virescence (RV); and potato purple top (PPT). Markers: phiX174, phiX174 Haelll digested; and pBR322, pBR322 Hael digested.

oil palm in Colombia (2) was classified and its molecular identity characterized. The phytoplasma was assigned to the 16SrI-B AY group, which was clearly differentiated from the other reference phytoplasma strains.

The association of more than one group of phytoplasmas with a specific set of disease symptoms at different locations is not unusual. Napier grass stunt disease in Kenya was shown to be associated with a phytoplasma from group $16 \mathrm{SrXI}$ (27) while, in Ethiopia, a phytoplasma from group $16 \mathrm{SrIII}$ was found associated with the same symptoms in Napier grass (26). These findings suggest that such phytoplasmas are being transmitted among plant species at these locations, although vectors have yet to be identified.

The epidemiological and etiological significance of the ability of phytoplasmas to move among plant species and into coconut and oil palm is unclear. Some phytoplasmas are known to be associated with "dead-end" hosts; that is, plants to which the vector can transmit pathogens but from which it cannot acquire them (52). For example, grapevine is a dead-end host for the stolbur phytoplasma, although this phytoplasma is associated with "bois noir" in grapevine. However, phytoplasmas are also known to have variable genomes and "potential mobile units" of DNA within their genomes (25). Spreading into dead-end hosts is a first step toward these phytoplasmas eventually becoming adapted to these new hosts. Future studies in comparative genomics on more phytoplasma sequences and identification of insect vectors will be key to determining how these organisms are evolving and adapting to old and new plant and insect hosts.

To our knowledge, this is the first time where a multigenic characterization of conserved genes other than 16S rDNA distinguished an AY strain in a specific host plant. The close association of this pathogen with oil palm lethal wilt disease was also confirmed because all symptomatic plants tested positive for the phytoplasma. In spite of the limitations of the data set in number of samples, sampling scheme, number of strains used for molecular characterization, and number of asymptomatic samples, the results of this survey provide important information and tools that can be employed to further study the disease. The epidemiology and insect vector identity can be defined for planning disease management strategies and containing further epidemics.

\section{Acknowledgments}

We thank the company Palmar del Oriente S.A., particularly F. Rodríguez and R. D. Bedoya, for financial and sampling support; and Palmas del Casanare, Palmeras Santana, and Palmeras del Upía for sampling and technical support.

\section{Literature Cited}

1. Alhudaib, K., Arocha, Y., Wilson, M., and Jones, P. 2008. First report of a 16SrI, 'Candidatus Phytoplasma asteris' group phytoplasma associated with a date palm disease in Saudi Arabia. Plant Pathol. 57:366.

2. Alvarez, E., and Claroz, J. L. 2003. Characterization and classification of phytoplasma associated with oil palm (Elaeis guineensis). Page 284 in: 8th Int. Congr. Plant Pathol. Australasian Plant Pathology Society, ed. Christchurch, New Zealand.

3. Alvarez, E., Mejía, J. F., Llano, G. A., Loke, J. B., Calari, A., Duduk, B., and Bertaccini, A. 2009. Detection and molecular characterization of a phytoplasma associated with frogskin disease in cassava. Plant Dis. 93:11391145 .

4. Barbara, D. J., Morton, A., Clark, M. F., and Davies, D. L. 2002. Immunodominant membrane proteins from two phytoplasmas in the aster yellows clade (chlorante aster yellows and clover phyllody) are highly divergent in the major hydrophilic region. Microbiology 148:157-167.

5. Bertaccini, A., Carraro, L., Davies, D., Laimer da Câmara Machado, M., Martini, M., Paltrinieri, S., and Seemüller, E. 2000. Micropropagation of a collection of phytoplasma strains in periwinkle and other host plants. Page 101 in: 13th Congr. IOM, Fukuoka, Japan.

6. Bertaccini, A., and Duduk, B. 2009. Phytoplasma and phytoplasma diseases: a review of recent research. Phytopathol. Mediterr. 48:355-378.

7. Brioso, P. S. T., Montano, H. G., Figueiredo, D. V., Poltronieri, L. S., and Furlan Junior J. 2006. Amarelecimento fatal do dendezeiro: seqüenciamento parcial do fitoplasma associado. Summa Phytopathol. 32:50.

8. Brown, S. E., Been, B. O., and McLaughlin, W. A. 2006. Detection and variability of the lethal yellowing group (16SrIV) phytoplasma in the $C e$ dusa sp. (Hemiptera: Auchenorrhyncha: Derbidae) in Jamaica. Ann. Appl Biol. 149:53-62.

9. Brown, S. E., Been, B. O., and McLaughlin, W. A. 2008. First report of lethal yellowing group (16SrIV) of phytoplasmas in Vernonia cinerea in Jamaica. Plant Dis. 92:1132.

10. Brown, S. E., Been, B. O., and McLaughlin, W. A. 2008. First report of the presence of the lethal yellowing group (16SrIV) of phytoplasmas in the weeds Emilia fosbergii and Synedrella nodiflora in Jamaica. Plant Pathol. 57:770. 
11. Cronjé, P., Dabek, A. J., Jones, P., and Tymon, A. M. 2000. Slow decline: a new disease of mature date palms in North Africa associated with a phytoplasma. Plant Pathol. 49:804.

12. Davis, R. E., and Lee, I.-M. 1993. Cluster specific polymerase chain reaction amplification of $16 \mathrm{~S}$ rDNA sequences for detection and identification of mycoplasmalike organisms. Phytopathology 83:1008-1011.

13. Deng, S., and Hiruki, C. 1991. Amplification of $16 \mathrm{~S}$ rRNA genes from culturable and non-culturable mollicutes. J. Microbiol. Methods 14:53-61.

14. Duduk, B., Calari, A., Paltrinieri, S., Duduk, N., and Bertaccini, A. 2009. Multi-gene analysis for differentiation of aster yellows phytoplasmas infecting carrots in Serbia. Ann. Appl. Biol. 154:219-229.

15. Duduk, B., Mejía, J. F., Paltrinieri, S., Contaldo, N., Alvarez, E., Varón, F., and Bertaccini, A. 2008. Molecular differentiation of phytoplasmas affecting corn in Colombia and Serbia. In CDrom: II Taller Internacional de Fitoplasmas, La Habana, Cuba.

16. EPPO/CABI (European and Mediterranean Plant Protection Organization, and CAB International). 1996. Apple proliferation phytoplasma. Pages 959962 in: Quarantine Pests for Europe, 2nd ed. I. M. Smith, D. G. McNamara, P. R. Scott, and K. M. Harris, eds. CAB International, Wallingford, UK.

17. FEDEPALMA. 2010. Es possible controlar la marchitez letal si se aplican las recommendaciones de Cenipalma. Palmicultor 458:12-15

18. Galetto, L., Fletcher, J., Bosco, D., Turina, M., Wayadande, A., and Marzachì, C. 2008. Characterization of putative membrane protein genes of the 'Candidatus Phytoplasma asteris', chrysanthemum yellows isolate. Can. J. Microbiol. 54:341-351.

19. Gilbertson, L., and Dellaporta, S. L. 1983. Molecular extraction DNA protocols. Pages 395-397 in: Molecular Biology of Plants. C. S. Harbor, ed. Cold Spring Harbor Laboratory Press, Cold Spring Harbor, NY.

20. Gundersen-Rindal, D. E., and Lee, I.-M. 1996. Ultrasensitive detection of phytoplasmas by nested-PCR assays using two universal primer pairs. Phytopathol. Mediterr. 35:144-151.

21. Hall, T. A. 1999. BioEdit: a user-friendly biological sequence alignment editor and analysis program for Windows 95/98/NT. Nucleic Acids Symp. Ser. 41:95-98.

22. Harrison, N. A., Helmick, E. E., and Elliot, M. L. 2008. Lethal yellowingtype diseases of palms associated with phytoplasmas newly identified in Florida, USA. Ann. Appl. Biol. 153:85-89.

23. Harrison, N. A., Helmick, E. E., and Elliott, M. L. 2009. First report of a phytoplasma-associated lethal decline disease of Sabal palmetto in Florida, USA. Plant Pathol. 58:789.

24. Harrison, N. A., Myrie, W., Jones, P., Carpio, M. L., Castillo, M., Doyle, M. M., and Oropeza, C. 2002. 16S rRNA interoperon sequence heterogeneity distinguishes strain populations of palm lethal yellowing phytoplasma in the Caribbean region. Ann. Appl. Biol. 141:183-193

25. Hogenhout, S. A., Oshima, K., Ammar, E. D., Kakizawa, S., Kingdom, H. N., and Namba, S. 2008. Phytoplasmas: bacteria that manipulate plants and insects. Mol. Plant Pathol. 9:403-423.

26. Jones, P., Arocha, Y., Sheriff, T., Proud, J., Abebe, G., and Hanson, J. 2007. A stunting syndrome of Napier grass in Ethiopia is associated with a 16SrIII group phytoplasma. Plant Pathol. 56:345.

27. Jones, P., Devonshire, B. J., Holman, T. J., and Ajanga, S. 2004. Napier grass stunt: a new disease associated with a $16 \mathrm{SrXI}$ group phytoplasma in Kenya. Plant Pathol. 53:519.

28. Kakizawa, S., Oshima, K., Jung, H.-Y., Suzuki, S., Nishigawa, H., Arashida, R., Miyata, S., Ugaki, M., Kishino, H., and Namba, S. 2006. Positive selection acting on a surface membrane protein of the plant-pathogenic phytoplasmas. J. Bacteriol. 188:3424-3428.

29. Kakizawa, S., Oshima, K., Nishigawa, H., Jung, H.-Y., Wei, W., Suzuki, S., Tanaka, M., Miyata, S., Ugaki, M., and Namba, S. 2004. Secretion of immunodominant membrane protein from onion yellows phytoplasma through the Sec protein translocation system in Escherichia coli. Microbiology 150:135-142.

30. Lee, I.-M., Gundersen-Rindal, D. E., Davis, R. E., Bottner, K. D., Marcone, C., and Seemüller, E. 2004. 'Candidatus Phytoplasma asteris', a novel phytoplasma taxon associated with aster yellows and related diseases. Int. J. Syst. Evol. Microbiol. 54:1037-1048.

31. Lee, I.-M., Zhao, Y., and Bottner, K. D. 2005. Novel insertion sequence-like elements in phytoplasma strains of the aster yellows group are putative new members of the IS3 family. FEMS Microbiol. Lett. 242:353-360.

32. Lee, I.-M., Zhao, Y., and Bottner, K. D. 2006. SecY gene sequence analysis for finer differentiation of diverse strains in the aster yellows phytoplasma group. Mol. Cell. Probes 20:87-91.

33. Lim, P. O., and Sears, B. B. 1992. Evolutionary relationships of a plant pathogenic mycoplasma-like organism and Acholeplasma laidlawii deduced from two ribosomal protein gene sequences. J. Bacteriol. 174:2606-2611.

34. Marcone, C., Lee, I.-M., Davis, R. E., Ragozzino, A., and Seemüller, E. 2000. Classification of aster yellows-group phytoplasmas based on combined analyses of rRNA and tuf gene sequences. Int. J. Syst. Evol. Microbiol. 50:1703-1713

35. Martini, M., Lee, I.-M., Bottner, K. D., Zhao, Y., Botti, S., Bertaccini, A. Harrison, N., Carraro, L., Marcone, C., Khan, A. J., and Osler, R. 2007. Ribosomal protein gene-based phylogeny for differentiation and classification of phytoplasmas. Int. J. Syst. Evol. Microbiol. 57:2037-2051.

36. Mitrović, J., Contaldo, N., Paltrinieri, S., Mejía, J. F., Mori, N., Bertaccini, A., and Duduk, B. 2011. The use of groEL gene in characterisation of aster yellows phytoplasmas in field collected samples. Bull. Insectol. (Suppl.) 64:S17-S18.

37. Mitrović, J., Kakizawa, S., Duduk, B., Oshima, K., Namba, S., and Bertaccini, A. 2011. The groEL gene as an additional marker for finer differentiation of 'Candidatus Phytoplasma asteris'-related strains. Ann. Appl. Biol. 159:41-48.

38. Montano, H. G., Brioso, P. S. T., and Pimentel, J. P. 2007. List of phytoplasma hosts in Brazil. Bull. Insectol. 60:129-130.

39. Nejat, N., Sijam, K., Abdullah, S., Vadamalai, G., and Dickinson, M. 2009. Phytoplasmas associated with disease of coconut in Malaysia: phylogenetic groups and host plant species. Plant Pathol. 58:1152-1160.

40. Nejat, N., Vadamalai, G., Davis, R. E., Harrison, N. A., Sijam, K., Dickinson, M., Abdullah, S. N., and Zhao, Y. 2012. 'Candidatus Phytoplasma malaysianum', a novel taxon associated with virescence and phyllody of Madagascar periwinkle (Catharanthus roseus). Int. J. Syst. Evol. Microbiol. doi:10.1099/ijs.0.041467-0

41. Ntushelo, K., Harrison, N. A., and Elliott, M. L. 2012. Comparison of the ribosomal RNA operon from Texas Phoenix decline and lethal yellowing phytoplasmas. Eur. J. Plant Pathol. 133:779-782.

42. Oropeza, C., Cordova, I., Chumba, A., Narváez, M., Sáenz, L., Ashburner R., and Harrison, N. 2011. Phytoplasma distribution in coconut palms affected by lethal yellowing disease. Ann. Appl. Biol. 159:109-117.

43. Pérez, A. P., and Cayón, G. 2010. Metabolism of carbohydrates in oil palms (Elaeis guineensis Jacq.) affected by lethal wilt. Agron. Colomb. 28:181187.

44. Prince, J. P., Davis, R. E., Wolf, T. K., Lee, I.-M., Mogen, B., Dally, E. Bertaccini, A., Credi, R., and Barba, M. 1993. Molecular detection of diverse mycoplasma-like organisms (MLOs) associated with grapevine yellows and their classification with aster yellows, X-disease, and elm yellows MLOs. Phytopathology 83:1130-1137.

45. Schneider, B., Ahrens, U., Kirkpatrick, B. C., and Seemüller, E. 1993 Classification of plant-pathogenic mycoplasma-like organisms using restriction-site analysis of PCR-amplified 16S rDNA. J. Gen. Microbiol 139:519-527.

46. Schneider, B., Seemüller, E., Smart, C. D., and Kirkpatrick, B. C. 1995 Phylogenetic classification of plant pathogenic mycoplasma-like organisms or phytoplasmas. Pages 369-380 in: Molecular and Diagnostic Procedures in Mycoplasmology. S. Razin and J. G. Tully, eds. Academic Press, New York

47. Tamura, K., Peterson, D., Peterson, N., Stecher, G., Nei, M., and Kumar, S. 2011. MEGA5: Molecular Evolutionary Genetics Analysis using maximum likelihood, evolutionary distance, and maximum parsimony methods. Mol. Biol. Evol. 28:2731-2739.

48. Thompson, J. D., Gibson, T. J., Plewniak, F., Jeanmougin, F., and Higgins, D. G. 1997. The CLUSTAL X windows interface: flexible strategies for multiple sequence alignment aided by quality analysis tools. Nucleic Acids Res. 25:4876-4882.

49. Tovar, J. P., and Torres, E. 2004. Estudio epidemiológico de la enfermedad marchitez letal de la palma de aceite en plantaciones de Villanueva, Casanare-Cenipalma. Palmas 25:210-219.

50. Turner, P. D. 1981. Oil Palm Diseases and Disorders. Oxford University Press, Oxford.

51. Warokka, J. 2005. Studies on the etiology and epidemiology of kalimantan wilt disease of coconut in Indonesia. Ph.D. diss. University of Nottingham, Nottingham, UK

52. Weintraub, P. G., and Beanland, L. 2006. Insect vectors of phytoplasmas Annu. Rev. Entomol. 51:91-111. 